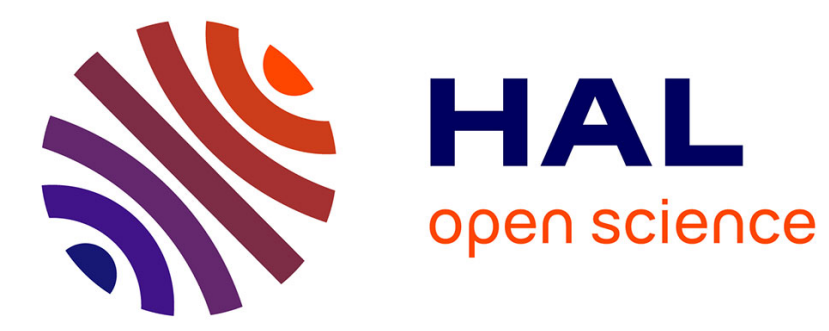

\title{
Ferritin, an iron source in meat for Staphylococcus xylosus?
}

\author{
Aurore Vermassen, Régine Talon, Sabine Leroy
}

\section{To cite this version:}

Aurore Vermassen, Régine Talon, Sabine Leroy. Ferritin, an iron source in meat for Staphylococcus xylosus?. International Journal of Food Microbiology, 2016, 225, pp.20-26. 10.1016/j.ijfoodmicro.2016.03.005 . hal-02636039

\section{HAL Id: hal-02636039 \\ https://hal.inrae.fr/hal-02636039}

Submitted on 27 May 2020

HAL is a multi-disciplinary open access archive for the deposit and dissemination of scientific research documents, whether they are published or not. The documents may come from teaching and research institutions in France or abroad, or from public or private research centers.
L'archive ouverte pluridisciplinaire HAL, est destinée au dépôt et à la diffusion de documents scientifiques de niveau recherche, publiés ou non, émanant des établissements d'enseignement et de recherche français ou étrangers, des laboratoires publics ou privés. 


\title{
Ferritin, an iron source in meat for Staphylococcus xylosus?
}

\author{
Aurore Vermassen, Régine Talon, Sabine Leroy * \\ INRA, UR454 Microbiologie, 63122 Saint-Genès Champanelle, France
}

\section{A R T I C L E I N F O}

\section{Article history:}

Received 30 November 2015

Received in revised form 19 February 2016

Accepted 5 March 2016

Available online 8 March 2016

\section{Keywords:}

Staphylococcus xylosus

Meat

Iron

Ferritin

Reductive pathway

\begin{abstract}
A B S T R A C T
Staphylococcus xylosus is frequently isolated from food of animal origin. Moreover, this species is one of the major starter cultures used for meat fermentation. Iron is a key element for growth and survival of bacteria. Meat is particularly rich in haemic (myoglobin and haemoglobin) and non-haemic (ferritin and transferrin) iron sources. Ferritin is a storage protein able to capture large quantities of iron. It is highly resistant to microbial attack and few microorganisms can use it as an iron source. Surprisingly, we found that the S. xylosus C2a strain grows in the presence of ferritin as a sole iron source. A three-cistron operon was highly overexpressed under ferritin iron growth conditions. We generated a deletion-insertion in the first gene of the operon and evaluated the phenotype of the mutant. The mutant showed decreased growth because it was less able to acquire iron from ferritin. Transcriptional analysis of the mutant revealed downregulation of several genes involved in the response to oxidative stress. This study characterized for the first time the capacity of a Staphylococcus to use iron from ferritin and revealed that a potential reductive pathway was involved in this acquisition. We hypothesize that this ability could give an advantage to $S$. xylosus in meat products.
\end{abstract}

(c) 2016 Elsevier B.V. All rights reserved.

\section{Introduction}

Staphylococcus xylosus belongs to the vast group of coagulasenegative staphylococci (CNS) and lives naturally on the skin and mucous membranes of mammals (Dordet-Frisoni et al., 2007; Götz et al., 2006; Nagase et al., 2002). So it occurs in foods of animal origin, such as meat, milk, fermented meat products and cheeses (Coton et al., 2010; Leroy et al., 2010). It is also used widely as a starter culture for meat fermentation (Talon and Leroy, 2011). S. xylosus has the ability to grow on meat and to survive during fermentation (Vermassen et al., 2014,2016 ) and for long periods of ripening during sausage manufacturing (Blaiotta et al., 2004; Corbière Morot-Bizot et al., 2006). The capacity of S. xylosus to use meat substrates has contributed to its adaptation to this environment. Meat is an iron-rich substrate but the bioavailability of iron is poor as it is complexed within heme as a cofactor for myoglobin or haemoglobin, or bound within ferritin or transferrin (Linder et al., 1981). Non-heme iron can range from 15 to $70 \%$ of total iron (about 2 to $5 \mu \mathrm{g} / \mathrm{g}$ ), depending on the type of meat (Lombardi-Boccia et al., 2002; Pereira and Vicente, 2013). The source of iron in meat used by S. xylosus is unknown.

For almost all bacteria, iron is a key element, required for survival and for many cellular processes (Wandersman and Delepelaire, 2004). Staphylococci have evolved a plethora of mechanisms to acquire iron from the host, including the elaboration of siderophores, the utilization

\footnotetext{
* Corresponding author.

E-mail addresses: regine.talon@clermont.inra.fr (R. Talon), sabine.leroy@clermont.inra.fr (S. Leroy).
}

of exogenous siderophores, the acquisition of iron from heme and haemoproteins, and the uptake of inorganic free iron (Beasley and Heinrichs, 2010; Haley and Skaar, 2012; Sheldon and Heinrichs, 2012). Among these mechanisms, two seem to be present only in pathogenic staphylococci. The first is the iron-regulated surface determinant (Isd) system, which allows the capture of heme from haemoglobin and its transfer into the cytoplasm, and has only been found in Staphylococcus aureus and Staphylococcus lugdunensis (Skaar and Schneewind, 2004; Zapotoczna et al., 2012). The second system has only been described for $S$. aureus and ensures the synthesis and transport of the staphyloferrin B (Dale et al., 2004). Most studies on iron acquisition have concerned the pathogenic $S$. aureus species and have focused on the acquisition of this essential element from haemoglobin or transferrin (Hammer and Skaar, 2011; Skaar et al., 2004). To our knowledge, nothing is known about ferritin iron acquisition by staphylococci.

Ferritin is a ubiquitous intracellular storage protein for iron. It is composed of 24 subunits, which self-assemble through non-covalent interactions into a hollow spherical shell, and contains up to 4500 iron atoms, making it a potentially rich iron source for bacteria. Ferritin uses $\mathrm{O}_{2}$ or $\mathrm{H}_{2} \mathrm{O}_{2}$ to catalyse oxidation of $\mathrm{Fe}(\mathrm{II})$ to $\mathrm{Fe}(\mathrm{III})$ and stores $\mathrm{Fe}(\mathrm{III})$ as an iron mineral core similar in structure to ferrihydrite (BouAbdallah, 2010). Ferritin is a remarkable iron source, but to acquire it bacteria must be able to remove it from this stable supramolecular complex.

There are few published reports describing microorganisms able to acquire iron from ferritin and even fewer characterizing the mechanisms. Ferritin iron acquisition in Listeria monocytogenes involves a surface-associated ferric reductase (Deneer et al., 1995) and Burkholderia cenocepacia uses a mechanism requiring proteolytic 
degradation of ferritin by a serine protease (Whitby et al., 2006). In Bacillus cereus, the surface protein Ilsa is absolutely required for ferritin iron acquisition (Daou et al., 2009). Recently, it was shown that this protein acts as a ferritin receptor, which causes the aggregation of ferritin on the surface of B. cereus (Segond et al., 2014). These authors have proposed a model of ferritin iron acquisition in $B$. cereus in which the surface protein enhances release of iron, uptake of which is then assisted by the siderophore bacillibactin (Segond et al., 2014). The opportunistic pathogen yeast Candida albicans captures ferritin though the invasion-like adhesin Als3, which is associated with hyphal morphology and uses a reductive pathway for iron uptake (Almeida et al., 2008). Moreover, C. albicans mediates acidification of the growth medium leading to dissociation of ferritin (Almeida et al., 2008).

Ferritin sequesters intracellular iron and is found in all tissues (Arosio et al., 2009) and so is one of the major sources of iron in meat as being a part of non-heme iron (Linder et al., 1981). Our preliminary data indicated that S. xylosus may acquire iron from this source and in a microarray study of the S. xylosus strain C2a, we identified three significantly upregulated genes that could be involved in the acquisition of iron from ferritin (our unpublished data). The homology-based annotation of these genes revealed that they can encode an oxidoreductase, a monooxygenase and a transporter, respectively. These genes have not yet been studied for any bacteria for their implication for iron acquisition. We have characterized the growth of S. xylosus in the presence of ferritin as a sole iron source and show that these three genes are transcribed as an operon encoding potential reductive uptake involved in ferritin iron acquisition.

\section{Materials and methods}

\subsection{Bacterial strains and growth conditions}

S. xylosus and Escherichia coli strains and plasmids used in this study are listed in Table 1. S. xylosus strains were serially precultured in polycarbonate Erlenmeyer flasks for $24 \mathrm{~h}$ at $30{ }^{\circ} \mathrm{C}$ with orbital shaking of $150 \mathrm{rpm}$ in $\mathrm{Mx0}$ medium unless otherwise indicated. Mx0 contained (per litre): $1 \mathrm{~g} \mathrm{Na}_{3}$-citrate $2 \mathrm{H}_{2} \mathrm{O}, 7 \mathrm{~g} \mathrm{Na}_{2} \mathrm{HPO}_{4} \cdot 2 \mathrm{H}_{2} \mathrm{O}, 3 \mathrm{~g} \mathrm{KH}_{2} \mathrm{PO}_{4}, 1 \mathrm{~g}$ $\mathrm{NaCl}, 1 \mathrm{~g} \mathrm{KCl}, 4 \mathrm{~g}\left(\mathrm{NH}_{4}\right)_{2} \mathrm{SO}_{4}, 0.5 \mathrm{~g} \mathrm{MgSO}_{4} \cdot 7 \mathrm{H}_{2} \mathrm{O}, 0.0147 \mathrm{~g} \mathrm{CaCl}_{2} \cdot 2 \mathrm{H}_{2} \mathrm{O}$, $4.6 \mathrm{mg}$ nicotinic acid, $2 \mathrm{mg}$ thiamine hydrochloride, $0.012 \mathrm{mg}$ biotin, $5 \mathrm{~g}$ glucose, and $6 \mathrm{~g}$ casamino acids. Iron-starved strains were subcultured at $30{ }^{\circ} \mathrm{C}$ in medium supplemented or not with horse spleen ferritin $(0.25,0.5,1$ or $5 \mu \mathrm{M})$ or $\mathrm{FeSO}_{4}(5,50,250$ or $500 \mu \mathrm{M})$. When needed, agar (Difco ${ }^{\mathrm{TM}}$ agar, Difco Laboratories, Detroit, MI, USA), containing or not bromocresol green as $\mathrm{pH}$ indicator, was added. A fresh solution of ferritin was passed through Amicon ultrafilter units $10 \mathrm{kDa}$ (Merck Millipore, Molsheim, France) to eliminate traces of released iron. E. coli was routinely grown under aerobic conditions in Luria-Bertani broth (Difco Laboratories) at $37{ }^{\circ} \mathrm{C}$. Cell growth was monitored by reading optical density at $600 \mathrm{~nm}$. Antibiotics were added at the following concentrations when necessary: for E. coli, $100 \mu \mathrm{g} / \mathrm{mL}$ ampicillin; for S. xylosus, $20 \mu \mathrm{g} / \mathrm{mL}$ chloramphenicol, and $2.5-10 \mu \mathrm{g} / \mathrm{mL}$ erythromycin. All chemicals were from Sigma-Aldrich (Saint-Quentin Fallavier, France).

\subsection{Bioscreen assay}

Precultures of S. xylosus strains in $\mathrm{Mx} 0$ were diluted in fresh $\mathrm{Mx} 0$ media supplemented or not with ferritin or $\mathrm{FeSO}_{4}$ to an $\mathrm{OD}_{600 \mathrm{~nm}}$ of 0.04 . Cells were grown at $30{ }^{\circ} \mathrm{C}$ in 100 -well microtitre plates with continuous shaking in a Bioscreen C plate reader (Labsystems France, Les Ulis, France). The $\mathrm{OD}_{600} \mathrm{~nm}$ was measured every $30 \mathrm{~min}$. Three independent experiments were done for each condition.

When needed, a protease inhibitor cocktail (P8465) was prepared according to the manufacturer's instructions (Sigma-Aldrich) and added. This cocktail contains AEBSF, sodium EDTA, bestatin, pepstatin $\mathrm{A}$ and E64 and has a broad specificity against serine, cysteine, and aspartic proteases, metalloproteases, and aminopeptidases. The concentrations tested were adjusted to have a final EDTA concentration between 0.2 to $2 \mathrm{mM}$ to avoid inhibition of bacterial growth.

\subsection{Genomic DNA isolation}

S. xylosus C2a gDNA was prepared from overnight cultures grown in Brain Heart Infusion (BHI) broth (Difco Laboratories) with shaking at $37{ }^{\circ} \mathrm{C}$. Briefly, cells were resuspended in Tris-EDTA-sucrose buffer containing $0.1 \mathrm{mg} / \mathrm{mL}$ lysostaphin (Sigma-Aldrich) and incubated for $30 \mathrm{~min}$ at $37^{\circ} \mathrm{C}$. Cells were lysed with sodium dodecyl sulphate and treated with RNase A. Following extraction with phenol-chloroformisoamyl alcohol (25/24/1) and chloroform, gDNA was precipitated with ethanol and resuspended in Tris- $\mathrm{HCl}(10 \mathrm{mM}$; $\mathrm{pH}$ 8.5). DNA was quantified using a NanoDrop 1000 spectrophotometer (Thermo Fisher Scientific, Wilmington, DE, USA).

\subsection{RNA extraction and purification}

S. xylosus was grown to mid-log phase and $15 \mathrm{~mL}$ of culture was centrifuged. The cell pellet was immediately frozen in liquid nitrogen to stabilize the bacterial RNA and stored at $-80^{\circ} \mathrm{C}$. For RNA extraction, the cell pellet was thawed on ice and resuspended in $500 \mu \mathrm{L}$ of ice-cold Tris-EDTA buffer. The sample was transferred to tubes containing $600 \mathrm{mg}$ of zirconia-silica beads $(0.1 \mathrm{~mm}$ diameter, BioSpec Products, Bartlesville, OK, USA), $50 \mu \mathrm{L}$ of sodium dodecyl sulphate (10\%), $3.5 \mu \mathrm{L}$ of $\beta$-mercaptoethanol, and $500 \mu \mathrm{L}$ of acid phenol. Cells were disrupted by two cycles of $60 \mathrm{~s}$ each at $6 \mathrm{~m} / \mathrm{s}$ by using a FastPrep (MP Biomedicals, Illkirch-Graffenstaden, France). After the addition of $200 \mu \mathrm{L}$ of chloroform and centrifugation, the aqueous phase was collected and purified with the Nucleospin RNA II kit (Macherey Nagel, Hoerdt, France) according to the manufacturer's instructions. A supplementary treatment was performed with Turbo DNAse (Ambion, Austin, TX, USA) to remove residual DNA. The absence of genomic DNA contamination was verified by PCR targeting the $r p o B$ gene. Total RNA isolated was quantified using a NanoDrop 1000 . The RNA was stored at $-80^{\circ} \mathrm{C}$.

\subsection{Reverse transcription and quantitative $P C R$}

RNA isolated from three independent biological replicates for each condition or each strain was reverse transcribed to cDNA with SuperScript Reverse Transcriptase according to the manufacturer's

Table 1

Strains and plasmids used in this study.

\begin{tabular}{|c|c|c|c|}
\hline & Name & Relevant characteristics & Source/Reference \\
\hline \multirow[t]{2}{*}{ S. xylosus } & $\mathrm{C} 2 \mathrm{a}$ & Derived from the type strain DSM20267 cured of its endogenous plasmid pSX267 & Götz et al., 1983 LN554884 \\
\hline & $\mathrm{C} 2 \mathrm{a} \Delta 561$ & Isogenic mutant of C2a deleted of the SXYL_00561 gene & This work \\
\hline E. coli & Top 10 & Competent strain for plasmid transformation & Invitrogen \\
\hline \multirow[t]{3}{*}{ Plasmids } & pBT2 & Temperature-sensitive E. coli-Staphylococcus shuttle vector. AmR (E. coli) CmR (Staphylococcus) & Brückner (1997) \\
\hline & $\mathrm{pSX} \Delta 561$ & pBT2, SXYL_00561 [13-317]: ermB shuttle vector & This work \\
\hline & pEC4 & pBluescript KS + derivative. Source of ermB gene (EmR). AmR & Brückner (1997) \\
\hline
\end{tabular}


instructions (Invitrogen, Cergy Pontoise, France). Quantitative PCR was performed using a Real Plex Master Cycler (Eppendorf, Hamburg, Germany) with $\mathrm{IQ}^{\mathrm{TM}}$ SYBR $®$ Green Supermix (Bio-Rad Laboratories, Hercules, CA, USA). Thermal cycling consisted of $30 \mathrm{~s}$ at $95^{\circ} \mathrm{C}$, followed by 40 cycles of $15 \mathrm{~s}$ at $95{ }^{\circ} \mathrm{C}$ and $60 \mathrm{~s}$ at $60^{\circ} \mathrm{C}$. The primer sequences of targeted genes are listed in Supplementary Table S1. All genes were quantified in duplicate for the three independent biological samples. The relative fold change of gene expression, using measured $r p o B$ housekeeping gene expression, was determined by the $2^{-\Delta \Delta \mathrm{Ct}}$ method (Livak and Schmittgen, 2001).

\subsection{Reverse transcription mapping}

To determine if SXYL_00561, SXYL_00562, SXYL_00563 of the cluster were co-transcribed, we mapped the mRNA species transcribed from this cluster. CDNA was subjected to PCR using pairs of primers targeting specifically each gene and each border junction of two adjacent genes (Table S1). Successful amplification would indicate the co-transcription of the two genes. The conditions for the amplification with GO Taq DNA polymerase (Promega, Charbonnières Les Bains, France) were $5 \mathrm{~min}$ at $95^{\circ} \mathrm{C}$, followed by 25 cycles of $30 \mathrm{~s}$ at $95^{\circ} \mathrm{C}$, $30 \mathrm{~s}$ at $60{ }^{\circ} \mathrm{C}$ and $30 \mathrm{~s}$ at $72{ }^{\circ} \mathrm{C}$ and finally $5 \mathrm{~min}$ at $72{ }^{\circ} \mathrm{C}$. Reactions with genomic DNA template were performed as a positive control. The PCR products were visualized in a $2 \%$ agarose gel.

\subsection{Construction of S. xylosus C2a $\Delta 561$ mutant strain}

To inactivate the SXYL_00561-00563 cluster, we made a deletion corresponding to amino acids 13 to 317 of the coding sequence and an insertion of an erythromycin resistance gene in the first gene of the operon (SXYL_00561) using the temperature-sensitive vector pBT2 (Brückner, 1997). A 2459-bp fragment was amplified using the primers Up561F1-EcoRI and Dn561R2-BamHI (Table 2) and purified with the QIAquick PCR purification kit (Qiagen, Hilden, Germany). A 694-bp upstream fragment and an 851-bp downstream fragment were separately amplified by using this fragment as template and the primer pairs Up561F1-EcoR1 and Up561R1-EmF, and Dn561F2-EmR and Dn561R2BamH1, respectively (Table 2). The ermB gene was amplified from the pEC4 vector (Brückner, 1997) using the primers EmF-Up561R and EmR-Dn561F (Table 2). The amplified fragment was 1366 bp. All amplifications were performed using Phusion High Fidelity DNA polymerase (New England Biolabs, Ipswich, MA, USA). The three PCR products were gel-purified with extraction from agarose using the QIAquick gel extraction kit (Qiagen). The two fragments flanking SXYL_00561 and the ermB gene were then annealed by overlapping PCR using the outside primers. The amplicon was gel-purified as described above and was restricted with the corresponding restriction enzymes and cloned into the temperature-sensitive shuttle vector $\mathrm{pBT} 2$. The resulting plasmid $\mathrm{pSX} \triangle 561$ was passaged through the E. coli TOP 10 , followed by recovery and electroporation into S. xylosus C2a using the method described by Brückner (1997). C2a containing pSX $\Delta 561$ was then selected for

\section{Table 2}

PCR primers for mutagenesis.

\begin{tabular}{|c|c|}
\hline Name & Primer sequence $\left(5^{\prime}-3^{\prime}\right)^{\mathrm{a}}$ \\
\hline Up561F1-EcoRI & CGGAATTCAACCACAGGCGGCATATAAT \\
\hline Dn561R2-BamHI & 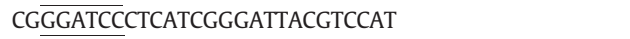 \\
\hline Up561R1-EmF & $\begin{array}{l}\text { CACAATAGAGAGATGTCACCCAATTGGACTTTGATCTAGAATAC } \\
\text { TCA }\end{array}$ \\
\hline Dn561F2-EmR ${ }^{\mathrm{b}}$ & GGTATACTACTGACAGCTTCCGTGAAAACGGTGGAGCAACT \\
\hline EmF-Up561R & $\begin{array}{l}\text { TGAGTATTCTAGATCAAAGTCCAATTGGGTGACATCTCTCTATTG } \\
\text { TG }\end{array}$ \\
\hline EmR-Dn561F & AGTTGCTCCACCGTTTTCACGGAAGCTGTCAGTAGTATACC \\
\hline Up561F3 & GCCTTACGATCGTTGGGTTA \\
\hline Dn561R3 & TGCACGATCAGCTATTGCAT \\
\hline
\end{tabular}

chloramphenicol resistance on $\mathrm{BHI}$ agar at $30^{\circ} \mathrm{C}$. A single colony was isolated, grown overnight in BHI broth at $30^{\circ} \mathrm{C}$ with $10 \mu \mathrm{g} / \mathrm{mL}$ erythromycin and subjected to erythromycin selection $(2.5 \mu \mathrm{g} / \mathrm{mL})$ for 4 days with regular dilution and subculture passages at $40^{\circ} \mathrm{C}$, a nonpermissive temperature for pBT2 replication. Bacteria were plated on BHI agar containing $2.5 \mu \mathrm{g} / \mathrm{mL}$ of erythromycin and then replica streaked on chloramphenicol BHI plates to screen for chloramphenicol-sensitive colonies. Double-crossover events corresponding to SXYL_00561 disruption and the presence of the $\operatorname{erm} B$ cassette were confirmed by PCR using primers Up561F3 and Dn561R3 (Table 2) and by DNA sequencing. The resulting strain was named C2a $\Delta 561$ (Table 1 ).

\subsection{In silico locus analysis}

The protein sequences of each gene from the SXYL_00561-00563 cluster of $S$. xylosus C2a were queried against the NCBI database using BLASTp to search for homologous sequences. The potential loci thus identified were visualized using the NCBI Sequence Viewer to look for any variation in the genetic organization.

\subsection{Nucleotide sequence accession number}

The GenBank accession number of the $S$. xylosus C2a sequence is LN554884.

\section{Results}

\subsection{S. xylosus can use ferritin as sole source of iron}

Using the Bioscreen $C$ plate reader, we measured the ability of the strain $S$. xylosus C2a to grow on various concentrations of ferritin in $\mathrm{Mx} 0$ medium and compared these growth curves with those obtained on various concentrations of $\mathrm{FeSO}_{4}$ (Fig. 1). S. xylosus growth was dependent on the concentrations of iron sources. Its growth was impaired in $\mathrm{Mx} 0$ iron-deficient medium. The addition of either $0.25 \mu \mathrm{M}$ ferritin or $5 \mu \mathrm{M} \mathrm{FeSO}$ in the medium allowed the growth of S. xylosus. A comparison of the effects of the different amounts of ferritin showed a dose-dependent growth enhancement (Fig. 1) with an increase of maximal growth rate $\left(\mu_{\max }=0.11,0.18,0.24\right.$, and $0.30 \mathrm{~h}^{-1}$ for $0.25,0.5,1$, and $5 \mu \mathrm{M}$ ferritin, respectively). The growth in the presence of $0.25 \mu \mathrm{M}$ ferritin was slightly limited and we noticed a prolonged lag phase and a lower cell density at $600 \mathrm{~nm}$ after $30 \mathrm{~h}$. Maximal growth rate was reached at the highest concentration of ferritin $(5 \mu \mathrm{M})$. In the presence of $\mathrm{FeSO}_{4}$, maximal growth rate was reached at $50 \mu \mathrm{M} \mathrm{FeSO}{ }_{4}\left(\mu_{\max }=\right.$ $0.23 \mathrm{~h}^{-1}$ ). Higher levels of $\mathrm{FeSO}_{4}$ did not result in growth enhancement (Fig. 1).

To further define the ability of S. xylosus C2a to utilize ferritin, we examined the possibility that ferritin iron acquisition requires acidification of the medium or proteolytic ferritin degradation to enhance the availability of iron. The $\mathrm{pH}$ of the medium remained stable at around 7.1 during growth in the presence of $5 \mu \mathrm{M}$ ferritin. Moreover, during the growth on $\mathrm{Mx} 0$ agar containing ferritin and bromocresol green, the strain C2a did not acidify the medium. The protease inhibitor cocktail, whatever the concentration tested, had no effect on the growth of the C2a strain in the $\mathrm{Mx} 0$ medium supplemented with 0.5 or $5 \mu \mathrm{M}$ ferritin as sole iron source (data not shown).

3.2. Transcriptional profiling of S. xylosus identified genes involved in ferritin iron acquisition

In a DNA microarray of S. xylosus C2a, we found that the expression of three co-localized genes, SXYL_00561, 00562 and 00563, was significantly upregulated during the growth on a medium containing ferritin as sole iron source (unpublished data). To carry out reverse transcription quantitative PCR (RT-qPCR) analysis, the S. xylosus C2a strain was grown in $\mathrm{Mx} 0$ medium in the presence of $5 \mu \mathrm{M}$ ferritin or $50 \mu \mathrm{M}$ 
A
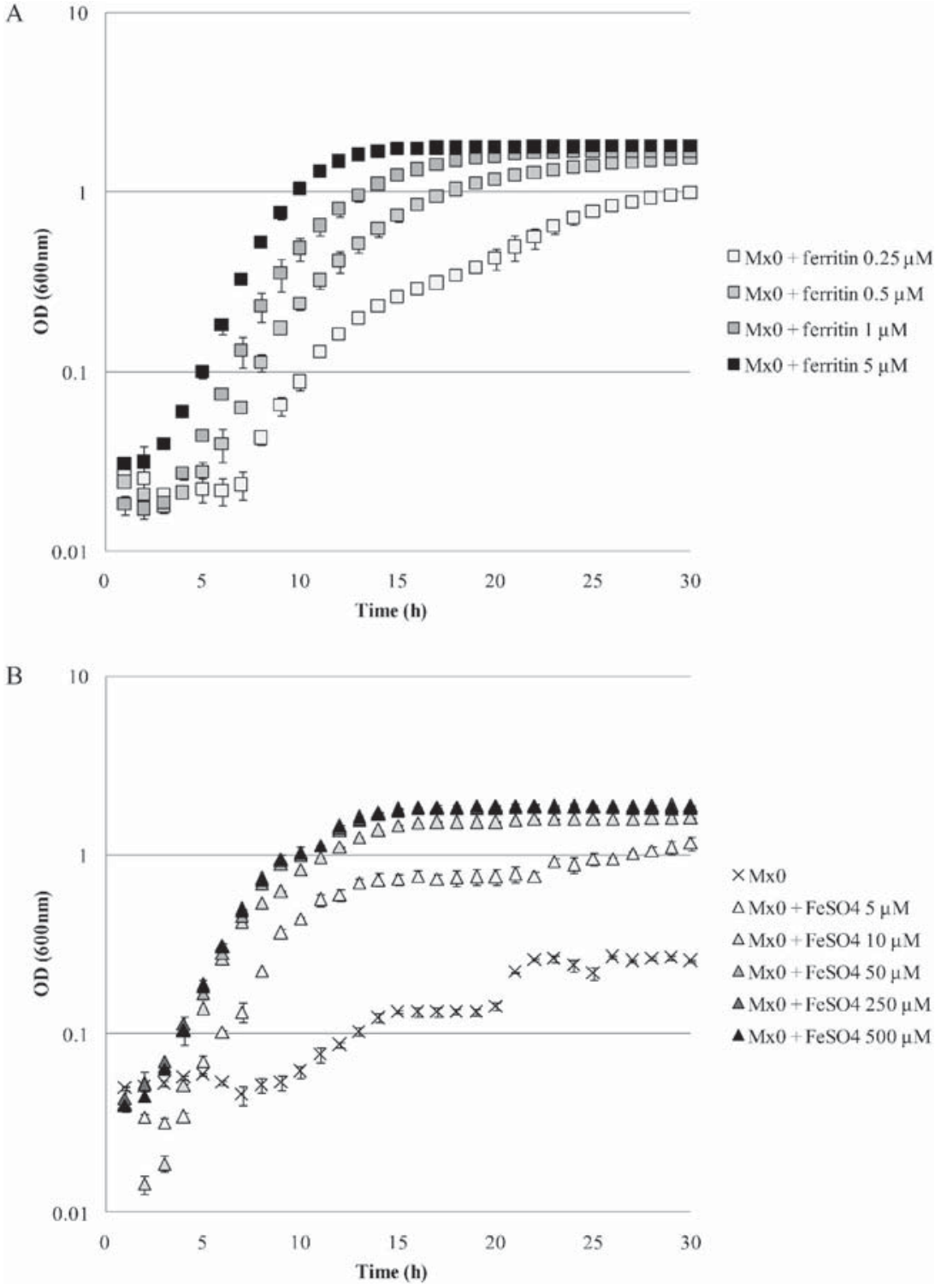

Fig. 1. Bioscreen growth curves of S. xylosus $\mathrm{C} 2$ a strain in $\mathrm{Mx} 0$ supplemented or not with ferritin (A) or $\mathrm{FeSO}_{4}$ (B). All experiments were performed in triplicate with three biological replicates. Error bars are standard errors of the mean and are not visible when smaller than the symbols.

$\mathrm{FeSO}_{4}$ in flasks with orbital shaking. No difference in growth was observed in these two conditions (Suppl. Fig. S1). After $8 \mathrm{~h}$ of culture, RNA was harvested from the cells in the exponential phase of growth for each condition and subjected to RT-qPCR to determine the expression of the three genes mentioned above and eight additional genes known to be involved in iron acquisition in staphylococci. The results, summarized in Table 3, confirmed that the three genes, SXYL_00561, SXYL_00562 and SXYL_00563, were highly overexpressed under ferritin iron growth conditions (Table 3 ). There was no significant difference in the expression of the five genes, sfaA, htsB, fhuC, sstA and sstD.

Table 3

Ratio of relative expression ( $5 \mu \mathrm{M}$ ferritin $/ 50 \mu \mathrm{M} \mathrm{FeSO}_{4}$ ) of the targeted genes in S. xylosus C2a strain.

\begin{tabular}{llll}
\hline Locus tag & Gene & Product of targeted gene & Ratio of relative expression determined by qPCR \\
\hline SXYL_00748 & SfaA & Transporter SfaA & 1.1 \\
SXYL_00752 & htsB & Iron compound ABC transporter, permease protein HtsB & 0.9 \\
SXYL_02203 & fhuC & ABC-type cobalamin Fe3 ${ }^{+}$-siderophore transport system ATPase component, FhuC & 0.8 \\
SXYL_02116 & SStA & Iron compound ABC transporter, permease protein SstA & 1.3 \\
SXYL_02113 & SstD & Lipoprotein SstD & 0.7 \\
SXYL_02216 & sitA & ABC metal ion transport system ATP-binding protein, SitA & $0.1^{*}$ \\
SXYL_02217 & sitB & Iron/manganese/zinc ABC transporter permease, SitB & $0.1^{*}$ \\
SXYL_02218 & sitC & ABC metal ion transport system extracellular binding protein, SitC & $0.2^{*}$ \\
SXYL_00561 & & Oxidoreductase & $22.0^{*}$ \\
SXYL_00562 & & Monooxygenase & $24.5^{*}$ \\
SXYL_00563 & & Transporter & $17.3^{*}$ \\
\hline
\end{tabular}

Each data point was calculated from the average of the duplicate for the three independent biological samples. A gene was considered differentially expressed under ferritin iron growth conditions compared with ferrous sulphate-replete growth conditions if the ratio of the relative expression was above 2 or below 0.5 as calculated with the $2^{-\Delta \Delta \mathrm{CT}}$ method $\left({ }^{*}\right)$. 
Expression of sitA, sitB and sitC decreased dramatically in the cells grown in the presence of ferritin compared with the growth in ferrous sulphate.

\subsection{Co-transcription of the gene cluster after growth on ferritin}

We used RT-PCR to establish whether the adjacent genes SXYL_00561, 00562 and 00563 were co-transcribed. The primers used were designed to amplify the $3^{\prime}$ end of the upstream gene, the intergenic sequence, and the $5^{\prime}$ end of the downstream gene. A PCR product with the expected size was obtained for each pair of genes (Fig. 2). Therefore, during growth on ferritin, these genes appeared to be co-transcribed and thus are organized as an operon.

\subsection{Inactivation of SXYL_00561-00563 operon modified S. xylosus growth} on ferritin

To analyse the contribution of the SXYL_00561-00563 operon to the capacity of $S$. xylosus to grow on ferritin as sole iron source, we constructed the $\mathrm{C} 2 \mathrm{a} \Delta 561$ mutant strain. The deletion of the first gene of this operon and the correct integration of the ermB cassette were confirmed by PCR and sequencing of the PCR product. After serial precultures on $\mathrm{Mx} 0$ to obtain iron-starved strains, the wild-type strain $\mathrm{C} 2 \mathrm{a}$ and the mutant strain $\mathrm{C} 2 \mathrm{a} \Delta 561$ were grown in $\mathrm{Mx} 0$ containing 0.5 or $5 \mu \mathrm{M}$ ferritin (Fig. 3). A significant difference in growth between both strains was observed at the two concentrations of ferritin. We observed an apparent extension of the lag period prior to the growth and a lower $\mu_{\max }$ for $\mathrm{C} 2 \mathrm{a} \Delta 561$ compared with the wild type $\left(0.13 \mathrm{~h}^{-1}\right.$ versus 0.19 at $0.5 \mu \mathrm{M}$ ferritin and $0.27 \mathrm{~h}^{-1}$ vs 0.30 at $\left.5 \mu \mathrm{M}\right)$. When both strains were grown in $\mathrm{Mx0}$ containing 50 or $500 \mu \mathrm{M} \mathrm{FeSO}$, no difference in growth was observed between the mutant and the wild type (Fig. 3 ).

3.5. Transcriptional profiling of the S. xylosus C2a $\Delta 561$ compared with the wild type in the presence of ferritin

The balance between uptake and storage of iron is of critical importance for bacteria in aerobic conditions, since iron in combination with oxygen mediates the generation of reactive oxygen species. We focused on the expression of 9 genes that responded to oxidative stress or were involved in iron storage (Table 4). The strain $\mathrm{C} 2 \mathrm{a}$ and the mutant $\mathrm{C} 2 \mathrm{a} \Delta 561$ were grown in Mx0 medium in the presence of $5 \mu \mathrm{M}$ ferritin in flasks with orbital shaking. RNA was harvested from the cells in the middle of growth exponential phase for each strain and subjected to RT-qPCR to determine the expression of the targeted genes. Among these, 3 genes, $k a t B$, katC, and bsaA, were downregulated in the strain $\mathrm{C} 2 \mathrm{a} \Delta 561$, with a ratio of relative expression lower than 0.5 (Table 4).

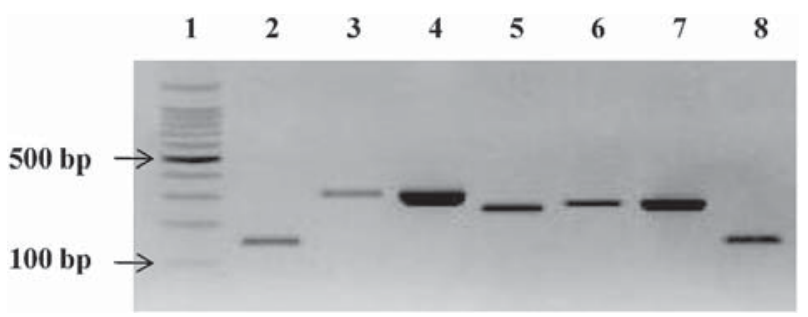

Fig. 2. Co-transcription of SXYL 00561-00562 and SXYL 00562-00563 as evidence by RTPCR mapping. Lane 1: molecular weight marker (Promega). Lanes 2, 5 and 8: positive controls of RT-PCR targeting the genes SXYL_00561, 00562 and 00563, respectively. Lanes 4 and 7: positive controls of PCR using genomic DNA as template, targeting the junction between SXYL_00561-00562 and SXYL_00562-00563, respectively. Lanes 3 and 6: the 310 bp and 270 bp RT-PCR products indicated a co-transcription of SXYL_0056100562 and SXYL_00562-00563, respectively.

\subsection{Presence of the cluster in other bacteria}

We identified loci homologous to SXYL_00561-00563 in only five other coagulase-negative Staphylococcus species, Staphylococcus saprophyticus, Staphylococcus equorum, Staphylococcus cohnii, Staphylococcus gallinarum and Staphylococcus arlettae (Fig. 4). In Staphylococcus succinus, only the two first genes were identified at this locus (Fig. 4). The location of the loci was quite similar, based on the available contigs (unavailable for S. arlettae). The loci were all followed at the 3' end by genes encoding a transcriptional regulator, a dehydrogenase and two subunits of a dihydroxyacetone kinase. The genes identified at the $5^{\prime}$ end of the locus were variable. For S. xylosus, S. saprophyticus and S. succinus, three genes encoding a short-chain dehydrogenase, a $\mathrm{Na}+/$ Pi-cotransporter and a phage infection protein were found. For S. equorum, the second and third genes were present. For S. gallinarum the first and third genes were present, while for S. cohnii only the second gene was identified.

\section{Discussion}

The ability to cope with environments where iron is sequestered is essential for the growth and survival of bacteria. Ferritin is a ubiquitous iron storage protein, but the acquisition of iron from ferritin has been demonstrated only for a limited number of bacteria (Deneer et al., 1995; Segond et al., 2014; Whitby et al., 2006). The present study shows for the first time that $S$. xylosus, a bacterium commonly isolated from meat products, is able to grow in the presence of ferritin as sole source of iron and that a potential reductive uptake system encoded by a three-cistron operon could be involved in ferritin iron uptake.

S. xylosus strain C2a showed limited growth under conditions of low iron concentration. Growth was restored by addition of ferritin to the medium and was optimal at $5 \mu \mathrm{M}$. To further define the ability of S. xylosus to acquire ferritin iron, we examined the possibility that the ferritin protein shell could be degraded by acidification or proteolytic process leading to iron release, as described for other microorganisms (Almeida et al., 2008; Whitby et al., 2006). S. xylosus does not cause a physical degradation by such processes and it is unclear how it alters the ferritin to promote iron release from the nanocage.

The expression of the three genes SXYL_00561, 00562 and 00563 was highly upregulated during the growth of $S$. xylosus on ferritin compared with incubation with ferrous sulphate. Furthermore, we observed marked downregulation of $s i t A B C$ genes, revealing their potential role in the acquisition of ferrous iron. These genes were first described in Staphylococcus epidermidis and encode an iron-regulated ABC transporter potentially involved in divalent metal uptake (Cockayne et al., 1998). The homologues of these genes in S. aureus named mntABC encode a transporter involved in the uptake of manganese (Horsburgh et al., 2002). As reported in the review by Sheldon and Heinrichs (2012), the role of this $\mathrm{ABC}$ transporter in iron acquisition is not completely elucidated. In S. xylosus, the expression of the sitABC genes was influenced by the presence of ferrous iron, but not by ferritin iron. No differential expression of the genes potentially involved in the production or transport of siderophores was observed under the two growth conditions. Indeed the expression of these genes was not modulated by the presence of ferritin iron or ferrous sulphate.

The three genes SXYL_00561, 00562 and 00563 formed an operon and were predicted to encode an oxidoreductase, a monooxygenase and a transporter, respectively. BLAST analyses demonstrated that this locus was only present in the species $S$. saprophyticus, S. equorum, S. cohnii, S. gallinarum and S. arlettae. In S. succinus, the last gene of this locus was missing. All these species, like S. xylosus, belong to the S. saprophyticus species group. Furthermore, the species $S$. equorum and S. saprophyticus, like S. xylosus, are often present in fermented meat products as a part of the indigenous microbiota (Janssens et al., 2013; Leroy et al., 2010; Talon and Leroy, 2011). The other species 
A

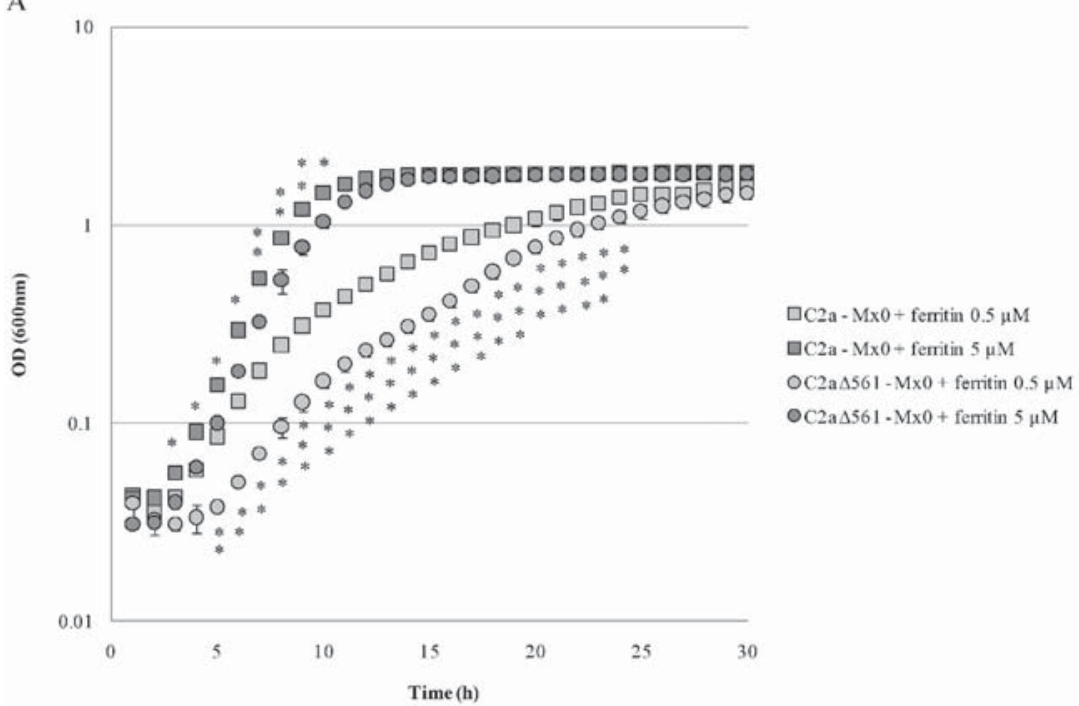

B

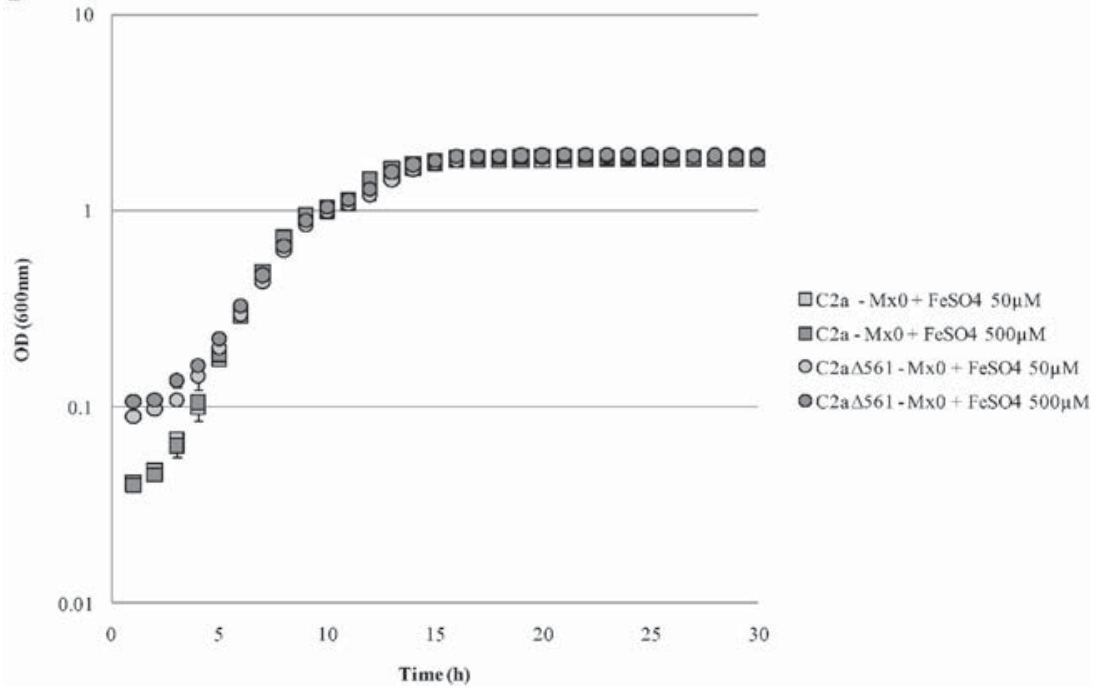

Fig. 3. Bioscreen growth curves of $S$. xylosus $\mathrm{C} 2 \mathrm{a}$ and $\mathrm{C} 2 \mathrm{a} \Delta 561$ strains in $\mathrm{Mx} 0$ containing ferritin $(\mathrm{A})$ or $\mathrm{FeSO}_{4}(\mathrm{~B})$. All experiments were performed in triplicate with three biological replicates. Error bars are standard errors of the mean and are not visible when smaller than the symbols. Data were statistically analysed using Student's t-test, with differences considered significant $\left(p<0.05,{ }^{*}\right)$, very significant $\left(p<0.01,{ }^{* *}\right)$ or highly significant $\left(p<0.001,{ }^{* * *}\right)$.

Table 4

Ratio of relative expression (S. xylosus $\mathrm{C} 2 \mathrm{a} \Delta 561 / \mathrm{C} 2 \mathrm{a}$ ) of the targeted genes in the presence of ferritin $(5 \mu \mathrm{M})$

\begin{tabular}{llll}
\hline Locus tag & Gene & Product of targeted genes & $\begin{array}{l}\text { Ratio of relative expression } \\
\text { determined by qPCR }\end{array}$ \\
\hline SXYL_01303 & sodA & Superoxide dismutase, SodA & 0.59 \\
SXYL_02505 & katA & Catalase A, KatA & 0.75 \\
SXYL_01551 & katB & Catalase B, KatB & $0.46^{*}$ \\
SXYL_02533 & katC & Catalase C, KatC & $0.37^{*}$ \\
SXYL_01572 & bsaA & Glutathione peroxidase, BsaA & $0.37^{*}$ \\
SXYL_02535 & ahpF & Alkyl hydroperoxide reductase & 0.76 \\
& & subunit F, AhpF & \\
SXYL_00793 & dps & Dps family protein, Dps & 0.63 \\
SXYL_00944 & ftnA & Ferritin, FtnA & 0.81 \\
SXYL_00973 & bcp & Bacterioferritin comigratory & 0.57 \\
& & protein, Bcp &
\end{tabular}

Each data point was calculated from the average of the duplicate for the three independent biological samples. A gene was considered differentially expressed under ferritin iron growth conditions compared with ferrous sulphate-replete growth conditions if the ratio of the relative expression was above 2 or below 0.5 as calculated with the $2^{-\Delta \Delta C T}$ method $(*)$.

\begin{tabular}{|c|c|c|}
\hline S. xylosus & SXYL_00561 SXYL_00562 & SXYL_00563 \\
\hline $\mathrm{C} 2 \mathrm{a}$ & $\begin{array}{l}\text { Oxidoreductase Monooxygenase } \\
\text { a WP_047171980 WP_047171981 }\end{array}$ & $\begin{array}{l}\text { Transporter } \\
\text { WP_042362150 }\end{array}$ \\
\hline S. saprophyticus & WP 011302476 WP_002482471 & WP 011302477 \\
\hline ATCC 15305 & $\mathrm{~b}_{76 \%}$ & $82 \%$ \\
\hline S. equorum & WP_002506823 WP_002506824 & WP_002506825 \\
\hline Mu2 & $83 \%$ & $80 \%$ \\
\hline S. cohnii & WP_046207588 WP_046207589 & WP_046207590 \\
\hline 57 & $66 \%$ & $79 \%$ \\
\hline S. gallinarum & WP_042739296 WP_042739297 & WP_042739298 \\
\hline DSM 20610 & $64 \%$ & $75 \%$ \\
\hline S. arlettae & WP_002509718 WP_002509719 & WP_002509720 \\
\hline CVD059 & $63 \%$ & $75 \%$ \\
\hline S. succinus & WP_046835793 WP_046835792 & absent \\
\hline DSM 14617 & $80 \%$ & \\
\hline
\end{tabular}

Fig. 4. Genetic organization of the S. xylosus SXYL_00561-00563 locus and protein sequence comparisons among coagulase-negative staphylococci belonging to the Staphylococcus saprophyticus species group. a: NCBI Reference Sequence, b: \% Identity. 
were also isolated from meat products but more sporadically (Greppi et al., 2015; Leroy et al., 2010).

Our phenotype study revealed that the deletion-insertion in the first gene of the three-cistron operon caused a growth deficiency for the cells grown with ferritin. Moreover, the inactivation of this operon led to downregulation of the genes katB, katC and bsaA, which encode catalases and glutathione peroxidase, respectively. These enzymes catalyse the reduction of $\mathrm{H}_{2} \mathrm{O}_{2}$ to $\mathrm{H}_{2} \mathrm{O}$ and are involved in the response to oxidative stress (Gaupp et al., 2012) or nitrosative stress (Vermassen et al., 2014). Like other bacteria, iron homeostasis in S. xylosus is intimately linked to mechanisms of defence against oxidative or nitrosative stress (Vermassen et al., 2014). Downregulation of these genes in the S. xylosus $\mathrm{C} 2 \mathrm{a} \triangle 561$ strain during growth under ferritin iron conditions may occur because the cell iron content is lower in the mutant strain than in the wild type, which may reduce oxidative stress. Several genetic studies have correlated oxidative stress with an increase in intracellular free iron (Touati, 2000).

In conclusion, $S$. xylosus uses a specific uptake system to acquire iron from ferritin. The capacity of this species, which is commonly used as meat starter culture, to acquire ferritin iron could be an advantage in terms of growth and survival in this ferritin-rich environment. Further studies are required to determine whether ferritin contributes to the adaptation to meat of $S$. xylosus but, also to the adaptation of S. saprophyticus and S. equorum, two other species also frequently isolated from meat products.

Supplementary data to this article can be found online at http://dx. doi.org/10.1016/j.ijfoodmicro.2016.03.005.

\section{Acknowledgements}

Aurore Vermassen was the recipient of a PhD Research Grant from the French 'Ministère de l'Education Nationale, de l'Enseignement Supérieur et de la Recherche (M.E.N.E.S.R.)'. We would like to thank Jean-Paul Chacornac and Carine Andant for technical assistance. The authors are grateful to David Marsh for correcting our English.

\section{References}

Almeida, R.S., Brunke, S., Albrecht, A., Thewes, S., Laue, M., Edwards Jr., J.E., Filler, S.G Hube, B., 2008. The hyphal-associated adhesin and invasin Als3 of Candida albicans mediates iron acquisition from host ferritin. PLoS Pathog. 4, e1000217.

Arosio, P., Ingrassia, R., Cavadini, P., 2009. Ferritins: a family of molecules for iron storage, antioxidation and more. Biochim. Biophys. Acta 7, 589-599.

Beasley, F.C., Heinrichs, D.E., 2010. Siderophore-mediated iron acquisition in the staphylococci. J. Inorg. Biochem. 104, 282-288.

Blaiotta, G., Pennacchia, C., Villani, F., Ricciardi, A., Tofalo, R., Parente, E., 2004. Diversity and dynamics of communities of coagulase-negative staphylococci in traditional fermented sausages. J. Appl. Microbiol. 97, 271-284.

Bou-Abdallah, F., 2010. The iron redox and hydrolysis chemistry of the ferritins. Biochim. Biophys. Acta 8, 719-731.

Brückner, R., 1997. Gene replacement in Staphylococcus carnosus and Staphylococcus xylosus. FEMS Microbiol. Lett. 151, 1-8.

Cockayne, A., Hill, P.J., Powell, N.B., Bishop, K., Sims, C., Williams, P., 1998. Molecular cloning of a 32-kilodalton lipoprotein component of a novel iron-regulated Staphylococcus epidermidis ABC transporter. Infect. Immun. 66, 3767-3774.

Corbière Morot-Bizot, S., Leroy, S., Talon, R., 2006. Staphylococcal community of a small unit manufacturing traditional dry fermented sausages. Int. J. Food Microbiol. 108, 210-217.

Coton, E., Desmonts, M.-H., Leroy, S., Coton, M., Jamet, E., Christieans, S., Donnio, P.-Y., Lebert, I., Talon, R., 2010. Biodiversity of coagulase-negative staphylococci in French cheeses, dry fermented sausages, processing environments and clinical samples. Int J. Food Microbiol. 137, 221-229.
Dale, S.E., Doherty-Kirby, A., Lajoie, G., Heinrichs, D.E., 2004. Role of siderophore biosynthesis in virulence of Staphylococcus aureus: identification and characterization of genes involved in production of a siderophore. Infect. Immun. 72, 29-37.

Daou, N., Buisson, C., Gohar, M., Vidic, J., Bierne, H., Kallassy, M., Lereclus, D., NielsenLeRoux, C., 2009. IlsA, a unique surface protein of Bacillus cereus required for iron acquisition from heme, hemoglobin and ferritin. PLoS Pathog. 5, e1000675.

Deneer, H.G., Healey, V., Boychuk, I., 1995. Reduction of exogenous ferric iron by a surface-associated ferric reductase of Listeria spp. Microbiology 141, 1985-1992.

Dordet-Frisoni, E., Dorchies, G., De Araujo, C., Talon, R., Leroy, S., 2007. Genomic diversity in Staphylococcus xylosus. Appl. Environ. Microbiol. 73, 7199-7209.

Gaupp, R., Ledala, N., Somerville, G.A., 2012. Staphylococcal response to oxidative stress. Front. Cell. Infect. Microbiol. 2, 33

Götz, F., Zabielski, J., Philipson, L., Lindberg, M., 1983. DNA homology between the arsenate resistance plasmid pSX267 from Staphylococcus xylosus and the penicillinase plasmid pI258 from Staphylococcus aureus. Plasmid 9, 126-137.

Götz, F., Bannerman, T., Schleifer, K.-H., Schleifer, K.-H., 2006. The genera Staphylococcus and Macrococcus. In: Dworkin, M., Falkow, S., Rosenberg, E., Stackebrandt, E. (Eds.), Prokaryotes, third ed. vol. 4. Springer, New York, pp. 5-75.

Greppi, A., Ferrocino, I., La Storia, A., Rantsiou, K., Ercolini, D., Cocolin, L., 2015. Monitoring of the microbiota of fermented sausages by culture independent rRNA-based approaches. Int. J. Food Microbiol. 212, 67-75.

Haley, K.P., Skaar, E.P., 2012. A battle for iron: host sequestration and Staphylococcus aureus acquisition. Microbes Infect. 14, 217-227.

Hammer, N.D., Skaar, E.P., 2011. Molecular mechanisms of Staphylococcus aureus iron acquisition. Annu. Rev. Microbiol. 65, 129-147.

Horsburgh, M.J., Wharton, S.J., Cox, A.G., Ingham, E., Peacock, S., Foster, S.J., 2002. MntR modulates expression of the PerR regulon and superoxide resistance in Staphylococcus aureus through control of manganese uptake. Mol. Microbiol. 44, 1269-1286.

Janssens, M., Myter, N., De Vuyst, L., Leroy, F., 2013. Community dynamics of coagulasenegative staphylococci during spontaneous artisan-type meat fermentations differ between smoking and moulding treatments. Int. J. Food Microbiol. 166, 168-175.

Leroy, S., Giammarinaro, P., Chacornac, J.P., Lebert, I., Talon, R., 2010. Biodiversity of indigenous staphylococci of naturally fermented dry sausages and manufacturing environments of small-scale processing units. Food Microbiol. 27, 294-301.

Linder, M.C., Nagel, G.M., Roboz, M., Hungerford Jr., D.M., 1981. The size and shape of heart and muscle ferritins analyzed by sedimentation, gel filtration, and electrophoresis. J. Biol. Chem. 256, 9104-9110.

Livak, K.J., Schmittgen, T.D., 2001. Analysis of relative gene expression data using realtime quantitative PCR and the $2^{-\Delta \Delta \mathrm{Ct}}$ method. Methods 25, 402-408.

Lombardi-Boccia, G., Martinez-Dominguez, B., Aguzzi, A., 2002. Total heme and non-heme iron in raw and cooked meats. Food Chem. Toxicol. 67, 1738-1741.

Nagase, N., Sasaki, A., Yamashita, K., Shimizu, A., Wakita, Y., Kitai, S., Kawano, J., 2002. Isolation and species distribution of staphylococci from animal and human skin. Int. J. Vet. Sci. Med. 64, 245-250.

Pereira, P.M.C.C., Vicente, A.F.R.B., 2013. Meat nutritional composition and nutritive role in the human diet. Meat Sci. 93, 586-592.

Segond, D., Abi Khalil, E., Buisson, C., Daou, N., Kallassy, M., Lereclus, D., Arosio, P., BouAbdallah, F., Nielsen Le Roux, C., 2014. Iron acquisition in Bacillus cereus: the roles of IlsA and bacillibactin in exogenous ferritin iron mobilization. PLoS Pathog. 10, e1003935

Sheldon, J., Heinrichs, D., 2012. The iron-regulated staphylococcal lipoproteins. Front. Cell. Infect. Microbiol. 2, 41.

Skaar, E.P., Schneewind, O., 2004. Iron-regulated surface determinants (Isd) of Staphylococcus aureus: stealing iron from heme. Microbes Infect. 6, 390-397.

Skaar, E.P., Humayun, M., Bae, T., DeBord, K.L., Schneewind, O., 2004. Iron-source preference of Staphylococcus aureus infections. Science 305, 1626-1628.

Talon, R., Leroy, S., 2011. Diversity and safety hazards of bacteria involved in meat fermentations. Meat Sci. 89, 303-309.

Touati, D., 2000. Iron and oxidative stress in bacteria. Arch. Biochem. Biophys. 373, 1-6.

Vermassen, A., de La Foye, A., Loux, V., Talon, R., Leroy, S., 2014. Transcriptomic analysis of Staphylococcus xylosus in the presence of nitrate and nitrite in meat reveals its response to nitrosative stress. Front. Microbiol. 5, 691.

Vermassen, A., Dordet-Frisoni, E., de La Foye, A., Micheau, P., Laroute, V., Leroy, S., Talon, R., 2016. Adaptation of Staphylococcus xylosus to nutrients and osmotic stress in a salted meat model. Front. Microbiol. 7, 87.

Wandersman, C., Delepelaire, P., 2004. Bacterial iron sources: from siderophores to hemophores. Annu. Rev. Microbiol. 58, 611-647.

Whitby, P.W., VanWagoner, T.M., Springer, J.M., Morton, D.J., Seale, T.W., Stull, T.L., 2006. Burkholderia cenocepacia utilizes ferritin as an iron source. J. Med. Microbiol. 55, 661-668.

Zapotoczna, M., Heilbronner, S., Speziale, P., Foster, T.J., 2012. Iron-regulated surface determinant (Isd) proteins of Staphylococcus lugdunensis. J. Bacteriol. 194, 6453-6467. 